\title{
Integrating Information Communication Technology Skills in Preschool Education in Kenya
}

\author{
Mauta P. Kaindio \\ School of Education, Mount Kenya University \\ kaindiomauta@yahoo.com \\ Margaret N. Wagithunu \\ School of Education, Mount Kenya University \\ Email: nwagithunu@gmail.com
}

\section{Doi:10.5901/mjss.2014.v5n5p}

\section{Abstract}

The study aimed at investigating the preparedness and attitude of ECDE teachers in preschools, and find out the current situation as far as ICT is concerned. The researchers adopted descriptive design. To obtain information on the current status of the ICT on whether there was any significant difference in preschool teachers' preparedness in terms of age, qualifications, and experience on ICT. 52 preschool teachers were randomly selected and a questionnaire administered to them. The data was analyzed using SPSS computer software. It was clear from the finding that Kenya is not ready to integrate ICT in preschool curriculum, since the physical facilities, electricity, poverty, trained personnel and teachers' attitudes towards ICT need to be addresses first.

Keywords: Education, Preschool, Learners, Information Communication Technology, Skills

\section{Introduction}

ICT have brought a rapid transformation of the economic, political and cultural society in general, known as the Information Society, indeed it has made the world a global village. It is therefore necessary that schools' curriculum adapts to the changing needs of the learners, so as not to be left behind in relation to social and cultural changes. Several initiatives have been undertaken with the aim of introducing ICT at various levels of education in schools; however there are few studies that relate to introduction of ICT in preschools.

We have witnessed a technological revolution that has brought many changes that are observed in our culture, education and in communication. In this information society, there is no impediment to knowledge acquisition. ICT makes Communication go beyond the barriers of space and time, and hence influencing the individuals in their way of thinking and acting. It is necessary for schools to adapt to the changing needs of their students so as not to become obsolete. It is also essential to answer the numerous challenges of our times that are characterized by technological change, due to rapid developments in technology, especially those associated with communications and computers.

\section{Methodology}

A quantitative methodology was used in this study, since it allowed the researchers to perform statistical analysis (mean, median, mode, standard deviation, hypotheses testing). Since the research aimed at collecting numerical data in order to establishing the status of preschools in Kenya in terms of ICT preparedness. According to Orodho (2004), quantitative methodology is important when the researcher intends to collect numerical data for coding, measurements, and hypothesis testing and generalize the results.

\section{Information Communication Technology and the Preschool Education}

It is necessary to meet the demands of society regarding the implementation of new technologies, so it has been suggested to schools the idea that such implementation should be initiated in an early stage, and should take place where young children obtain a training base used throughout life. 
ICT enables expanded access to knowledge, multiplying the learning situations because they are an inexhaustible resource to the potential of "information superhighways". Computers should be seen as flexible and powerful tools that improve teaching and learning. The needs of individual children are met in a more attractive and exciting way. They promote independence and provide access to a wide range of information, encouraging children to explore and create ideas. With a computer we are able to access games and other interesting activities, with different methods of presenting educational content that captivate children and adults at the same time.

Research on the subject has shown that an appropriate use of information technology develop skills such as language development and literacy, written language, mathematical concepts, cognitive abilities, stimulate imagination and creativity, develop collaboration, fine motor skills, among other areas. The internet and e-mail have also been referenced by many authors as valuable communication tools and information production.

ICT can be defined as anything which allows us to get information, to communicate with each other, or to have an effect on the environment using electronic or digital equipment. In early childhood education (ECE), the term ICT could include computer hardware and software, digital cameras and video cameras, the Internet, telecommunication tools, programmable toys, and many other devices and resources. The study suggests at least three reasons why ICT matters in early childhood education. First, ICT already has an effect on the people and environments that surround young children's learning. Second, these technologies offer new opportunities to strengthen many aspects of early childhood education practice. Third, there is support and interest across the whole education sector for the development and integration of ICT into education policy, curriculum, and practice. However, there is a clear consensus in the literature that the introduction and use of ICT in early childhood education should be grounded in a clear understanding of the purposes, practices, and social context of early childhood education.

There is a growing recognition of the many different ways that ICT can contribute to, or transform, the activities, roles, and relationships experienced by children and adults in early childhood education settings. The literature indicates the importance of practitioners and other adults in early childhood education settings having guidance and opportunities to become capable, competent, and informed about the educational role and potential of ICT, and support to use ICT to strengthen many aspects of early childhood education practice. However, in the last few years there has also been a growth in research and descriptive literature about the use of other kinds of ICT in early childhood education, including digital cameras, digital video, closed-circuit television, videoconferencing, programmable toys, robotics, and electronic musical instruments.

There is also a growing focus on teachers using ICT with children, or on their own, as a tool to support and scaffold children's early childhood education experiences, to investigate and build learning experiences from children's interests, or to strengthen relationships between children, practitioners, and families. Case studies and examples of the use of ICT in early childhood education settings are becoming more and more common. These are often written by early childhood education practitioners, and provide recommendations, suggestions, or guidelines for other practitioners based on what the authors have learned in their own centers.

\subsection{Information Communication Technology and the Child}

Some authors have expressed the view that computer/ICT use is not appropriate for young children's cognitive, physical, social, and emotional development. However, there is no clear evidence to support this claim, and this view has increasingly been replaced by the view that, when used appropriately, ICT can be a useful tool for supporting young children's learning and development. Most authors note the need for practitioners to be aware of health and safety issues around children's use of ICT, and for these to be attended to in early childhood education center ICT policies and practices. This includes: attention to children's physical safety and ergonomic issues; being mindful against children's exposure to inappropriate content e.g. games or Internet-based material of violence or of sexual nature, or containing undesirable gender or cultural stereotypes; and protection of children's privacy e.g. in online environments, or when information is published on the internet.

Studies suggest that ICT use can provide a context for collaboration, co-operation, and positive learning experiences between children, or between children and adults. However, this will not necessarily happen of its own accord. Research indicates that practitioners must be conscious of the kinds of learning interactions they would like to occur in the context of ICT use including between adults and children, or between children, and adopt pedagogical strategies to support these. Case studies show how ICT can be used to support aspects of learning, including language development and the development of mathematical thinking. ICT also provides unique opportunities for scaffolding and supporting learning for children with special learning needs, and children from culturally or linguistically diverse backgrounds. ICT provides a variety of ways for children to weave together words, pictures, and sounds, thereby 
providing a range of ways for children to communicate their ideas, thoughts, and feelings. Good software can allow children to engage in self-directed exploration, and can be tailored to children's individual needs, and assistive/adaptive ICTs can reduce barriers to participation for children with special physical or learning needs.

\subsection{Information Communication Technology for Enhancing Childhood Learning Environment}

Studies which explores how ICT can enhance the learning environment in early childhood education suggests that the value ICT can add to young children's learning environments depends on the choices practitioners make about which tools to select, and when and how to use these; and their understandings about how these tools can support children's learning, development, and play. To make these choices, practitioners need to be familiar with various tools and what they can do. They also need to be familiar with contemporary theories about learning and development, and recognize how these can be linked to the use of ICT. New kinds of practices may be needed, for example, to support young children to develop information and communication illiteracies necessary for learning in ICT-enriched environments.

Case studies show how early childhood education practitioners have used ICT to support a range of practices they believe to directly or indirectly support children's learning and development. These include: directly supporting and scaffolding children's use of ICT; using ICT to document and assess children's learning and activities; using ICT to reflect on children's and educators' interactions in the early childhood education setting; using ICT to build curricula from children's interests, ideas, and experiences; and using ICT to strengthen and support family involvement in children's learning.

\subsection{Information Communication Technology Professional Development for Childhood Educators}

Without good guidance, examples, and support for their own professional learning, early childhood educators will make their own decisions about the nature and extent of ICT use in children's learning. These decisions are influenced by such factors as educators' own level of confidence with ICT, and their beliefs about learning and teaching in the early childhood years. Literature about ICT use in early childhood education settings, and studies of early childhood teachers and teachers-in-training learning to use ICT, suggest that effective professional development supports teachers to develop understandings of ICT that connect with their existing early childhood education philosophy and pedagogical views. Effective ICT professional development incorporates teachers' own aspirations, skills, knowledge, and understanding into the learning context. It provides opportunities for teachers to learn and explore new ways of working in their own early childhood education setting, and stimulates practitioners to reflect on their views and ideas about children's learning and development, and to analyze and question how things are done in early childhood education.

Effective professional development emphasizes collaborative knowledge-building, and practitioners sharing their situated learning experiences with ICT with one another. It provides support networks to help practitioners to be active researchers in their own early childhood education setting, and to access current research and expertise in ICT.

Our choice to develop this work in Preschool education and related with technologies was based on several reasons. The first reason concerns the fact that the pre-school is an educational level that hasn't had much attention by research and technological innovation, so little is known about the potential for their use within this level of education. Another aspect relates to the results of current research. These results have demonstrated the importance of familiarizing young children with technology, either because it is unquestionably part of the world that surrounds, as well as the relevance of educational experiences that it can provide. It is true that, despite much having been written about the integration of Information Communication Technology in school there are several studies that show the rates and usage, percentages, numbers of users, ratio of pupils to computers, applications used, etc. there are however hardly any studies that describe and analyze the actual process of integrating technology in pre-school education.

\subsection{A theorization of Information Communication Technology Significance in Preschool}

Preschool classes lay the future learning foundation. This may become possible by making sure that preschoolers are acquainted with the common framework for lifelong learning skills. So, how do teachers working within the ECDE, especially those who are working within preschool classes, make education interesting, purposive, learner centered, practical, engaging, supportive, relevant, and experiential? In order for this generation of techno savvy children to find classroom activities interesting, while still maintaining the free atmosphere of a preschool in which most "classroom" activities are based on individual abilities, introduction if ICT is necessary. In our piloting study, 20 preschool classroom teachers were used in order to assess the validity and reliability of the instrument. 


\subsection{Information Communication Technology in Preschool Class}

Most preschools today have started using surfpad's and smartboards' since they are suitable for early learners, as market results show such gadgets can be used directly using fingers by interaction. Whereas preschool classes nationwide there has been very little changes when it comes to IT and ICT within pedagogical work. In a study on inclusion of digital media within early childhood education conducted by Klerfelt (2010), shows that utilization of IT and ICT does not mean that one stops using conventional methods such as paper and pens. By including computers and digital technology, students interact and reflect on a different level than that of their predecessors.

Since current generation of children are grown up with watching their parents and elders communicating with such gadgets rather than pen and paper it is important that preschool class teacher make use of them as part of pedagogical and didactical methods from the very start. In an ICT integrated classroom, information flow is very different from non-ICT integrated classrooms. One such program is Symwriter and the most powerful feature is the "talk back" factor. This allows students to hear what they have written letter for letter, word for word. Thus, the student in preschool class, immaterial to what level they are at, can hear the phonetic formation of letters and words opposed to feeling like sitting ducks and waiting for the teacher to attend to them.

Everyone plays computer games, not just the most talented. In fact, one can find all the ingredients in a game, which are similar to what schools try to impart. Most games are built on the same principles such as stimulating, challenging and at the end a reward. The difference is that in a gaming or digitalized situation the player interacts and is given space and time to solve the problems they encounter, on their own level, without experiencing any negative feeling of not reaching the level. One possibility could be that they can always start over! (Papworth \& Wallin 2005).

\subsection{Development and Integration of Information Communication Technology in Education Sector}

There is now a strong focus on the development of ICT policy and integration of ICT in curriculum and practice across the whole education sector. ICT and e-learning have become important concepts in primary, secondary, and tertiary education. In most countries, policy and curriculum support for the development of ICT in the early childhood education sector have lagged behind that given to the school sector (O'Hara, 2004; Sheridan \& Pramling Samuelsson, 2003; Stephen \& Plowman, 2003). This situation is beginning to change. Some countries, like Scotland, have recently developed ICT strategies for the early childhood education sector (Learning and Teaching Scotland, 2003b). Researchers, academics, and practitioners in early childhood education have also published books, articles, and guidelines which provide information and guidance about ICT in early childhood, and aim to support early childhood education practitioners to make well-informed decisions and choices about ICT (Downes, Arthur, \& Beecher, 2001; NAEYC, 1996; O'Hara, 2004; Siraj-Blatchford \& Siraj-Blatchford, 2003).

The delayed attention to ICT in early childhood education presents some advantages for the sector. For example, the growth and development of ICT in the school sector has sometimes been driven by the desire to get more technology and technological infrastructure into schools, without sufficient attention given to the pedagogical purposes for introducing the technology, or the supporting conditions and resources that might enable the technologies to contribute towards better teaching and learning experiences.

In many countries, heavy investments have been made in ICT for use by teachers and students but the purposes of these investments have not always been clear or made explicit (Higgins, 2003). While there is evidence from schoolsector research that ICT can help pupils to learn and teachers to teach more effectively (Higgins, 2003), research has also uncovered many examples in which the widespread rollout of ICT into schools has done little to improve or transform teaching practice, or students' learning experiences in any meaningful way (Peck, Cuban, \& Kirkpatrick, 2002; Reynolds, 2002). The evidence is clear that simply providing ICT equipment to schools or teachers will not necessarily make a difference; what makes the difference is the way in which this equipment and other resources are used (Higgins, 2003).

The early childhood education sector may find useful guidance from some of the school-sector ICT literature. For example, research into effective teacher professional development with respect to ICT (e.g. Ham, 2002), and the conditions that facilitate innovation in the use and integration of ICT in teaching and learning (e.g. Harris \& Kington, 2002; Tubin, Mioduser, Nachmias, \& Forkosh-Baruch, 2003; Zhao, Pugh, Sheldon, \& Byers, 2002). Some of this research will be discussed in Section 6. However, it is also important to recognise the differences between the two sectors, and to recognise where there are limits for translating school-based research findings to early childhood education contexts. For example, within the school-sector ICT literature, there has been a strong focus on measuring the effects of linking the use of ICT in terms of assessments of student learning or achievement (Lewin, Scrimshaw, Harrison, Somekh, \& McFarlane, 2000; Schacter, 1999). 
The concepts of "learning" and "achievement" are usually defined relative to the age level(s) of the students, and the learning goals and intentions that underpin specific instances of ICT use. These learning intentions are often connected with particular subject areas in the curriculum. Other areas featured in the school-sector ICT literature may have strong resonance within the ECE sector. For example, the role or potential for ICT to Support professional communities of learning among teachers (both within and between different schools); strengthen school-community relationships or increase the involvement of parents, and other people outside schools, in students' school learning experiences.

\subsection{Need To Supporting Children's Capability and Information Communication Technology Literacy}

Information and communication technologies are becoming more embedded and ubiquitous in the environment around children. These technologies are having such a profound effect on all aspects of people's lives that they are now becoming taken-for-granted. Children today live in a communication-rich environment. The models of communication they encounter in their everyday lives include... a whole range of electronic and digital methods of communication...there are electronic forms of communication in the outdoor environment, in streets as cash machines or pedestrian crossings and in supermarkets and much more (Siraj-Blatchford \& Siraj-Blatchford, 2003, p. 4).

It is highly likely that ICT will continue to be a significant presence in children's learning environments throughout their schooling and into their adult lives. In order to be full and capable participants in their environments, authors like Siraj-Blatchford and Whitebread consider it important that young children begin to develop "technological literacy". They define this as:

...a new form of literacy, but it is one that is increasingly considered to represent an essential curriculum entitlementin any broad and balanced curriculum for the twenty-first century (Siraj-Blatchford \& Whitebread, 2003, p. 1).

The UK Foundation Stage ${ }^{1}$ curriculum reflects this view. It states that as part of their early childhood education, children should find out about and identify the uses of everyday technology, and that children should have opportunities to use ICT to support their learning (Becta., 2004). Similarly, Swedish authors Sheridan and Pramling-Samuelsson argue that: Just as it is every child's right to become literate, he or she should have the right to become a skilful user of ICT. Children should...experience ICT as a tool with vast possibilities for communication and information retrieval/sharing (Sheridan \& Pramling Samuelsson, 2003, p. 267). "Foundation Stage" refers to education for children aged between 3 and 5 years. Downes and Fatuoros (1995) make the point that to be effective lifelong learners; children will need to be literate in the communication modes of their culture. They need to be able to make, and make sense of, "texts" (whether these be print-based, electronic, or image-based).

For young children, this could mean developing skills in the use of images and sounds to convey information, ideas, and feelings. Multimedia ICT tools present many possibilities for doing this. Learners in the "information age" will also need to develop skills to organize and analyses information (Downes \& Fatuoros, 1995). Recognizing the way that ICT and other multimedia technologies shape this information is an important part of this process. However, learners will not only be consumers of information - they will also be producers and creators of information (Downes \& Fatuoros, 1995). For young children, this could involve using electronic media to record information, ideas, and feelings about themselves, their activities, and their environments, to share these with others.

Other contextual factors to explain the lack of ICT use in early childhood education could include: teachers' limited training opportunities in the use of ICT; insufficient equipment or funds to buy equipment; absence of on-site technical support; or a lack of time to develop ICT-integrated teaching or learning activities (O'Hara, 2004). However, if more time, equipment, or training is to be provided to practitioners, this support must also acknowledge practitioners' views and beliefs about children's learning and development, and bring these to the foreground of ICT support and professional development provision for the sector.

This includes research to find out about access to, and use of, ICT across different early childhood education settings (Bain, 2000; Brooker, 2003; Downes et al., 2001; Kankaanranta, 2001), or the relationships between children's ICT experiences at home and in early childhood education settings (Brooker \& Siraj-Blatchford, 2002; Downes, 2002). These studies reflect an "ecological" view of young children's ICT experiences. They seek to investigate the interactions between factors in children's home backgrounds (including the interactions of ethnicity/culture and language, gender, and economic/social status) and their early experiences of ICT, and how these factors impact on the knowledge, skills, dispositions, and feelings children display around computers in their early childhood education settings.

This type of research acknowledges that children in different locations or from different family backgrounds will 
have different experiences of childhood, and that when it comes to ICT, not all children will be starting from the same point. It acknowledges that children will have different levels of interest, confidence, and prior knowledge and skills when it comes to ICT use. It recognizes that some children may have special learning needs, while others may be gifted or talented in some way, and that this must be taken into consideration when supporting young children's experiences with ICT (O'Hara, 2004).

\section{Empirical Discussions}

\subsection{Ratio of Female to Male Early Childhood Education (ECDE) Teachers n Private And Public Schools Interviewed}

\begin{tabular}{|cc|c|c|c|}
\hline \multirow{2}{*}{} & \multicolumn{2}{|c|}{ Type of school } & \multirow{2}{*}{ Total } \\
\cline { 3 - 4 } & private & public & \\
\hline \multirow{2}{*}{ Gender of respondent } & Male & 8 & 19 & 27 \\
Total & Female & 17 & 8 & 25 \\
& & 25 & 27 & 52 \\
\hline
\end{tabular}

In private schools, the ratio of male to female was 1:2, and in public school the ratio is 2:1.

From the analysis above, male teachers prefer teaching in public ECDE schools as compared to female teachers who prefer private schools.

\subsection{Relationship between Teaching Experience And Age Of ECDE Teachers}

\begin{tabular}{|cc|c|c|}
\hline & & Teaching experience & Age bracket \\
\hline \multirow{3}{*}{ Teaching experience } & Pearson Correlation & 1 & $.499^{* *}$ \\
& Sig. (2-tailed) & & .000 \\
& $\mathrm{~N}$ & 52 & 52 \\
\hline \multirow{2}{*}{ Age bracket } & Pearson Correlation & $.499^{* *}$ & 1 \\
& Sig. (2-tailed) & .000 & \\
& $\mathrm{~N}$ & 52 & 52 \\
\hline
\end{tabular}

Correlation is significant at the .01 level (2-tailed).

At .499 calculated values, there is significant relationship between the age and experience of teachers in ECDE schools at .01 confidence level. This means that as the age of ECDE teachers' increases, their experience also increases.

\subsection{Academic Qualification of ECDE Teachers}

\begin{tabular}{|c|c|c|c|c|c|}
\hline \multirow{2}{*}{\multicolumn{3}{|c|}{ Academic qualification }} & \multicolumn{2}{|c|}{ type of school } & \multirow{2}{*}{ Total } \\
\hline & & & private & public & \\
\hline \multirow{3}{*}{ KCSE } & \multirow{2}{*}{ Gender of respondent } & MALE & 8 & 18 & 26 \\
\hline & & Female & 17 & 8 & 25 \\
\hline & \multicolumn{2}{|l|}{ Total } & 25 & 26 & 51 \\
\hline \multirow{2}{*}{ KACE } & Gender of respondent & \multirow{2}{*}{ MALE } & & 1 & 1 \\
\hline & Total & & & 1 & 1 \\
\hline
\end{tabular}

All ECDE teachers in both private and public schools have KCSE academic qualifications. 


\subsection{Professional Qualification of ECDE Teachers}

\begin{tabular}{|c|c|c|c|c|c|}
\hline \multicolumn{6}{|c|}{ Count } \\
\hline \multirow{2}{*}{\multicolumn{3}{|c|}{ Professional qualification }} & \multicolumn{2}{|c|}{ type of school } & \multirow[t]{2}{*}{ Total } \\
\hline & & & private & public & \\
\hline \multirow{3}{*}{ ECDE certificate } & \multirow{2}{*}{ Gender of respondent } & Male & 4 & 6 & 10 \\
\hline & & Female & 5 & 3 & 8 \\
\hline & \multicolumn{2}{|l|}{ Total } & 9 & 9 & 18 \\
\hline \multirow{3}{*}{ ECDE diploma } & \multirow{2}{*}{ Gender of respondent } & Male & 2 & 5 & 7 \\
\hline & & Female & 8 & 1 & 9 \\
\hline & \multicolumn{2}{|l|}{ Total } & 10 & 6 & 16 \\
\hline \multirow{3}{*}{ P1 } & \multirow{2}{*}{ Gender of respondent } & Male & 2 & 8 & 10 \\
\hline & & Female & 4 & 4 & 8 \\
\hline & Total & & 6 & 12 & 18 \\
\hline
\end{tabular}

All ECDE teachers in both public and private schools have some kind of professional qualifications. Those with ECDE certificate in private and public schools, the ratio is 1:1, but those with ECDE diploma in private are more (63\%) as compared to public schools (37\%). The trend reverses with PI professional qualifications where in public schools $67 \%$ have P1 certificate compared to private schools with $33 \%$. For one to be trained as a P1 one requires to have attained a mean grade of $C$ plain at KCSE, but for one to be trained for ECDE diploma may require a low grade of even $D$ - at KCSE level. This means that Public ECDE schools are taught by better qualified teachers.

\subsection{ICT Training of ECDE Teachers}

\begin{tabular}{|c|c|c|c|c|c|}
\hline \multirow{2}{*}{\multicolumn{3}{|c|}{ ICT training }} & \multicolumn{2}{|c|}{ Type of school } & \multirow{2}{*}{ Total } \\
\hline & & & private & public & \\
\hline \multirow{3}{*}{ Certificate in computer studies } & \multirow{2}{*}{ Gender of respondent } & \multirow{3}{*}{$\begin{array}{c}\text { Male } \\
\text { Female }\end{array}$} & 2 & 7 & 9 \\
\hline & & & 9 & 4 & 13 \\
\hline & Total & & 11 & 11 & 22 \\
\hline \multirow{2}{*}{ Diploma in computer studies } & Gender of respondent & \multirow[t]{2}{*}{ Male } & 1 & & 1 \\
\hline & Total & & 1 & & 1 \\
\hline \multirow{3}{*}{ ICT skills without certificate } & \multirow{2}{*}{ Gender of respondent } & \multirow{3}{*}{$\begin{array}{c}\text { Male } \\
\text { Female }\end{array}$} & 5 & 12 & 17 \\
\hline & & & 8 & 4 & 12 \\
\hline & Total & & 13 & 16 & 29 \\
\hline
\end{tabular}

$56 \%$ of ECDE teachers do not have any formal ICT training. $42 \%$ have certificate in ICT training, and only $2 \%$ had Diploma in ICT training and who were found in private schools. Those who have certificate in ICT training in private and public schools the ratio is 1:1 which is similar to those who have ICT training without certificate. More female ECDE teachers have formal ICT training (25\%) compared to male ECDE teachers (17\%). More male ECDE teachers do not have formal ICT training (33\%) compared to female ECDE teachers (23\%)

\subsection{Availability of Computers in ECDE Schools}

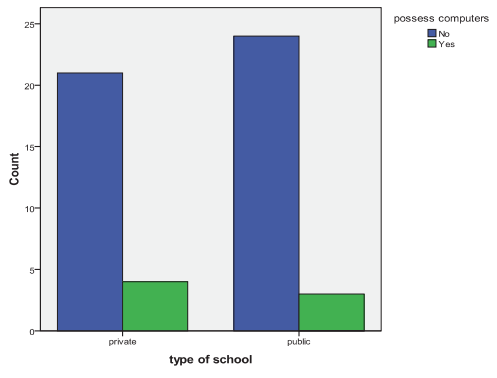


The above graph shows that most schools in both private and public do not own computers. More private schools have computers as compared to public schools.

\subsection{Usage of Computers}
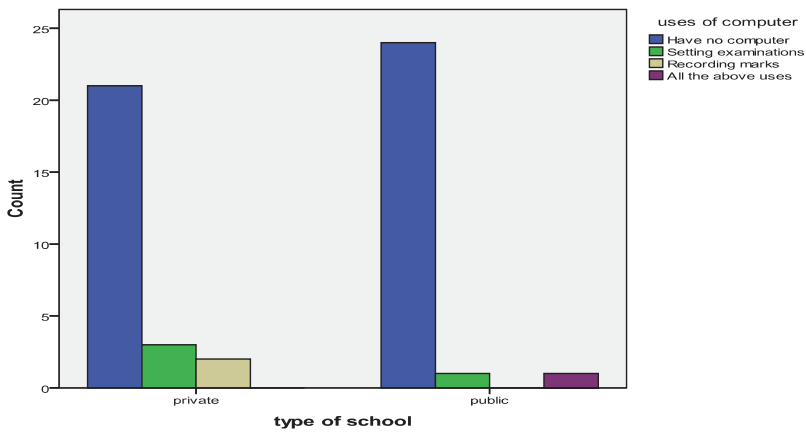

The graph above shows that most schools do no not have computers, and the few who own computers, use them for examination setting and marks recording.

\subsection{Enrolments of Nursery School Pupils in Schools}

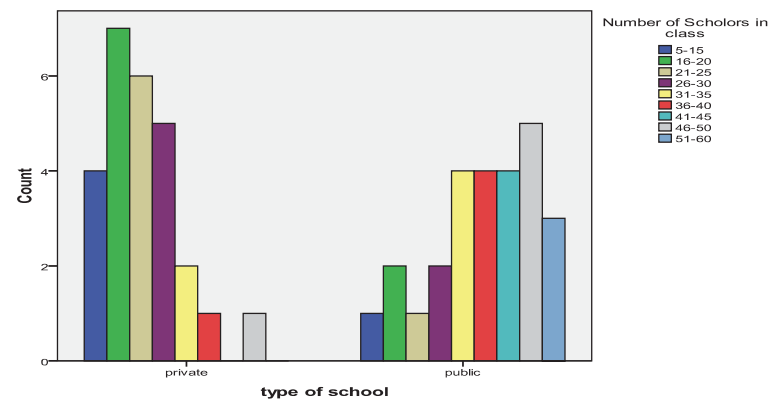

The analysis above shows that in private schools, most classes have between $16-20$ pupils. While in public schools, most classes have between 46-50 pupils. It means that in public schools, the classes are congested compared to private schools. For this reason, teaching and learning may not be as effective as in private schools due to high number of pupils per class.

4.9 Number of Pupils Who Wear Shoes

Count

\begin{tabular}{|rc|c|c|c|c|c|}
\hline & \multicolumn{4}{|c|}{ Approximate number who wear shoes } & \multirow{2}{*}{ Total } \\
\cline { 2 - 6 } & & About 25\% & About 50\% & About 75\% & About all of them & \\
\hline \multirow{2}{*}{ type of school } & private & 0 & 1 & 1 & 24 & 26 \\
& public & 23 & 3 & 0 & 0 & 26 \\
Total & 23 & 4 & 1 & 24 & 52 \\
\hline
\end{tabular}

In private ECDE schools $92 \%$ of pupils wear shoes while going to school compared to $88 \%$ pupils in public schools who do not wear shoes. 


\subsection{Adequacy of desks in ECDE classrooms}

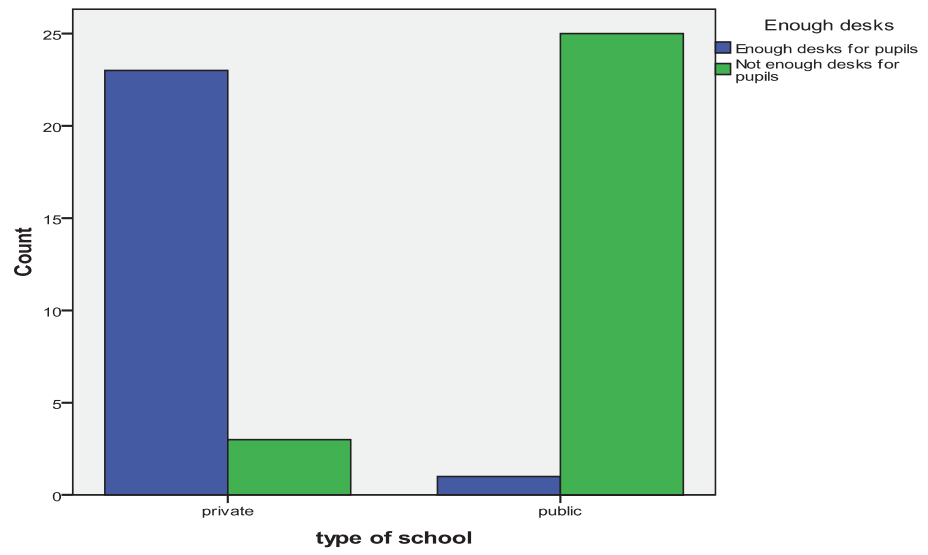

In private school classrooms (92\%) have enough desks compared to public schools where desks are not enough (96\%).

\subsection{Availability of electricity in ECDE classrooms}

\begin{tabular}{|cc|c|c|c|}
\hline & \multicolumn{2}{|c|}{ Availability of electricity } & \multirow{2}{*}{ Total } \\
\cline { 3 - 4 } & No & Yes & \\
\hline \multirow{2}{*}{ type of school } & private & 18 & 8 & 26 \\
Total & public & 21 & 5 & 26 \\
& & 39 & 13 & 52 \\
\hline
\end{tabular}

Most ECDE schools, both public and private do not have electricity (75\%).

However more private schools have electricity connections (31\%) compared to public schools (19\%).

\subsection{Availability of electric sockets in ECDE classrooms}

\begin{tabular}{|cc|c|c|c|c|}
\hline \multirow{2}{*}{} & \multicolumn{3}{|c|}{ Number of sockets } & \multirow{2}{*}{ Total } \\
\cline { 3 - 5 } & None & $1-2$ & $3-4$ & \\
\hline \multirow{2}{*}{ type of school } & private & 18 & 6 & 2 & 26 \\
& public & 21 & 5 & 0 & 26 \\
\hline & & 39 & 11 & 2 & 52 \\
\hline
\end{tabular}

For those few schools that has electricity supply, most of them have between 1 - 2 electric sockets per classroom.

\subsection{Safety of computers}

\begin{tabular}{|rc|c|c|c|c|}
\hline & \multicolumn{3}{|c|}{ Safety of computers } & \multirow{2}{*}{ Total } \\
\cline { 3 - 5 } & & & No & Yes & \\
\hline \multirow{2}{*}{ type of school } & private & 7 & 10 & 9 & 26 \\
& public & 9 & 14 & 3 & 26 \\
Total & & 16 & 24 & 12 & 52 \\
\hline
\end{tabular}

Most respondents (46\%) felt that computers safety would not be guaranteed. However in private schools more respondents felt that computers are safer (35\%) compared to public schools (12\%) respondents feelings. 
4.14 Attitudes of stakehoders on ICT integration in preschool curriculum

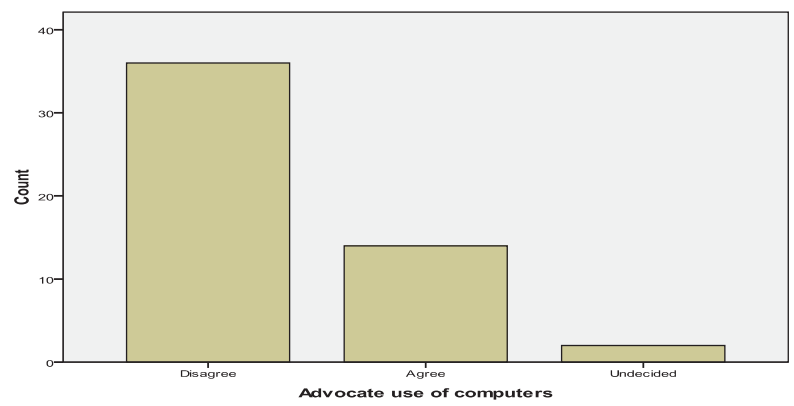

Most respondents (71\% disagreed) do not advocate the use of computers for learning and teaching in nursery school.

\subsection{Attitude of people on whether ICT integration would increase learners interest}

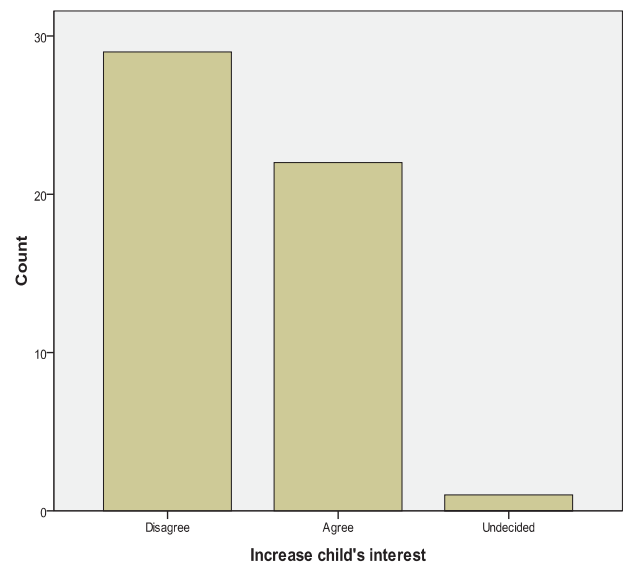

About $56 \%$ of respondents disagreed that ICT increases pupils' interest in learning. This means that most respondents (56\%) do not advocate the ICT integration in ECDE curriculum.

\subsection{Attitude of people on ICT effect on pupils' academic performance}

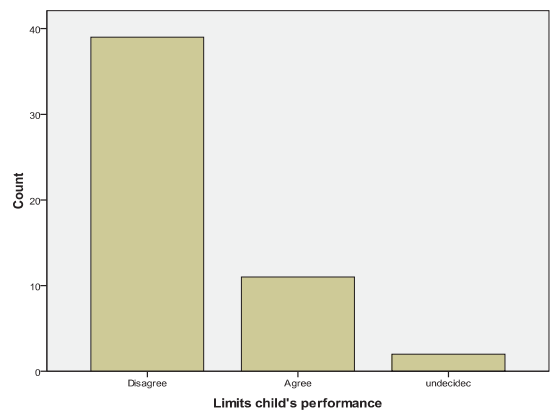

$74 \%$ of respondents disagreed that inclusion of ICT in preschool curriculum cannot limit pupils academic performance. 
4.17 Attitude of people on ICT inclusion and preschool syllabus coverage

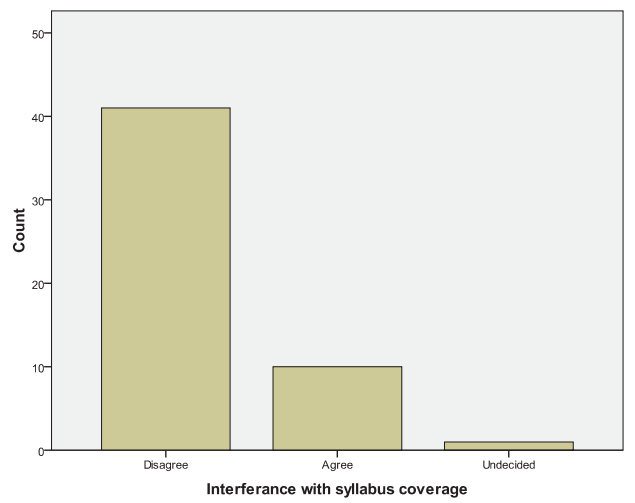

$79 \%$ disagreed that inclusion of ICT would interfere with syllabus coverage in preschool curriculum.

\subsection{Attitude of ECDE teachers on laptop program in standard one}

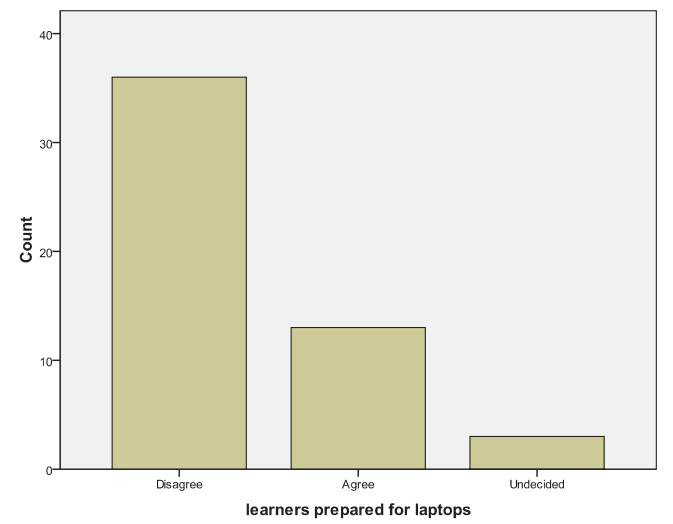

$69 \%$ of respondents (ECDE teachers) disagreed that inclusion of ICT in preschool curriculum will prepare the pupils for standard one lap top program.

\section{Conclusion}

The data collected clearly shows that most of respondents did not advocate introduction of ICT in preschool curriculum. Schools are not ready for ICT integration for the fact that almost all the institution do not have electricity, a very important factor for the success implementation. The few institution has electricity connection, do not have even enough sockets to power the computer. The attitudes of the stakeholders need to change before the introduction of ICT in preschool for the government to expect their support.

\section{References}

Advisory Group on the Review of the Centre. (2001). Report of the Advisory Group on the Review of the Centre. http://www.ssc.govt.nz/searchset.htm

Amante, L. (2004). Explorando as novas tecnologias em contexto de educação pré-escolar: a actividade de escrita. Análise Psicológica, 1 (22), 139-154.

Bain, J. (2000). Managing computers in teaching and administration in kindergartens. Computers in NZ Schools, 12 (1), 21-32. 
Becta. (2004). Video conferencing in the curriculum. Case study 2: Chalvey Early Years Centre, Slough. E-storytelling. British Educational Communications and Technology Agency. Retrieved 30 June 2004, from http://www.ltscotland.org.uk/earlyyears/casestudies.asp

Brooker, L. (2003). Integrating new technologies in UK classrooms: Lessons for teachers from early years practitioners. Childhood Education Annual, 79 (5), 261-267.

Carr, M. (2001). Assessment in early childhood settings: Learning stories. London: Paul Chapman Publishing.

Clements, D. (2002). Computers in early childhood mathematics. Contemporary Issues in Early Childhood: Technology Special Issue, 3 (2), 160-181.

Clements, D. H. and Nastasi, B. K. (2002). Os Meios Electrónicos de Comunicação e a Educação de Infância. In Manual de investigação em Educação de Infância, B. Spodek (org), Fundação Calouste Gulbenkian, Lisboa, pp. 561-619.

Clements, D. H. and Nastasi, B. K. (2002). Os Meios Electrónicos de Comunicação e a Educação de Infância. In Manual de investigação em Educação de Infância, B. Spodek (org), Fundação Calouste Gulbenkian, Lisboa, pp. 561-619.

Cooper, V., Farquhar, Z., \& McLean, V. (2001). The use of information and communication technologies in the early years (3-8 yearolds): Research from the Warriparri cluster in South Australia 2000-2001. South Australia: Report sponsored by the e-education project.

Cordes, C., \& Miller, E. (Eds.). (2000). Fool's gold: A critical look at computers in childhood. College Park, Maryland: Alliance for Childhood.

Davis, B., \& Shade, D. (1994). Integrate, don't isolate! Computers in the early childhood curriculum. ERIC Clearinghouse on Elementary and Early Childhood Education.

Dockett, S., Perry, B., \& Nanlohy, P. (1999). Computers in early childhood services: A part of the educational program or less time for play? Journal of Australian Research in Early Childhood Education, 6 (2), 165-176.

Downes, T. (2002). Children's and families' use of computers in Australian homes. Contemporary Issues in Early Childhood: Technology Special Issue, 3 (2), 182-196

Downes, T., Arthur, L., \& Beecher, B. (2001). Effective learning environments for young children using digital resources: An Australian perspective. Information Technology in Childhood Education Annual, 139-153.

Downes, T., \& Fatouros, C. (1995). Young children learning in their preschool and primary years: A framework for planning to incorporate IT. Australian Educational Computing, May, 4-9.

Elkind, D. (1998). Computers for infants and young children. Child Care Information and Exchange, 9, 44-46.

Graham, M. J., \& Banks, S. R. (2000). Young children's initial exploration of computers. In D. Rothenberg (Ed.), Issues in early childhood education. Curriculum, teacher education, and dissemination of information. Proceedings of the Lilian Katz Symposium, November 5-7. (pp. 357-364). Urbana-Champaign: ECAP collective.

Haggerty, M. (1998). Sighting, citing and siting Te Whāriki: exploring the use of video feedback as a tool for critical pedagogy. The experiences of five early childhood centres. Unpublished Master of Education thesis, Victoria University, Wellington.

Ham, V. (2002). What makes for effective teacher development in ICT? An evaluation of the 23 ICTPD school clusters progamme 19992001: Christchurch College of Education, Report to the Ministry of Education. Harris, J. (2001). The effects of computer games on young children - a review of the research. RDS occasional paper no. 72. London: The Research, Development and Statistics Directorate.

Harris, S., \& Kington, A. (2002). Innovative classroom practices using ICT in England: Implications for schools. Slough: National Foundation for Education Research.

Haugen, K. (1998). Using technology to enhance early learning experiences. Child Care Information and Exchange, 9, 47-56.

Haugland, S. (2003). Selecting developmentally appropriate software. Children and computers. Retrieved 30 June, 2004, from http://www.childrenandcomputers.com/Articles/selecting_developmentally_approp.htm

Hill, S., \& Broadhurst, D. (2001). Technoliteracy and the early years. In L. Makin \& C. Jones Diaz (Eds.), Literacies in early childhood: Changing views, challenging practice (pp. 269-287). Eastgardens, N.S.W.: MacLennan and Petty.

Hong, S., \& Broderick, J. (2003). Instant video revisiting for reflection: Extending the learning of children and teachers. Early Childhood Research and Practice, 5 (1). Retrieved 30 June 2004, from http://ecrp.uiuc.edu/v5n1/hong.html

Jones, A. (2002). Integrating ICT in the early years: Literacy, math and multimedia. Retrieved 30 June 2004, from http://www.pa.ash.org.au/acec2002/

Jordan, B. (1999). Technological tools supporting the scaffolding of learning. New Zealand Research in Early Childhood Education, 2 , $53-66$.

Kalinowski, M. (1998). A look at child care administrative software. Child Care Information Exchange, Jan-Feb 1998 (119), 28-32.

Kankaanranta, M. (2001). Constructing digital portfolios: Teachers evolving capabilities in the use of information and communications technology. Teacher Development, 5 (2), 259-276.

Kankaanranta, M., \& Kangalasso, M. (2003). Information and communication technologies in Finnish early childhood. Childhood Education, 79 (5), 287-293.

Katz, Y. (2003). The use of virtual reality three-dimensional simulation technology in nursery school teacher training for the understanding of children's cognitive perceptions. In G. Marshall \& Y. Katz (Eds.), Learning in school, home, and community. ICT for early and elementary education (pp. 41-51). Boston: Kluwer Academic Publishers.

Kerslake, A. (1998). Computerisation of the "looking after children" records: Issues of implementation. Children and Society, 12, 236237. 
Labbo, L. D., Sprague, L., Montero, M. K., \& Font, G. (2000). Connecting a computer center to themes, literature and kindergarteners' literacy needs. Reading Online, 4 (1). Retrieved 30 June 2004, from http://www.readingonline.org/electronic/labbo/index.html

Laffey, J. (2003). Appropriation, mastery and resistance to technology in early childhood preservice teacher education. Journal of Research on Technology in Education, 36 (4), 361-382.

Learning and Teaching Scotland. (2003a). 'Come back in two years!' A study of the use of ICT in pre-school settings. Scotland. Retrieved 25 March 2004, from

http://www.Itscotland.org.uk/earlyyears/ComeBackinTwoYears.asp

Learning and Teaching Scotland. (2003b). Early learning, forward thinking: the policy framework for ICT in early years. Scotland. Retrieved 25 March 2004, from

http://www.ltscotland.org.uk/earlyyears/files/ict_framework.pdf

Lee, W., Hatherly, A., \& Ramsey, K. (2002). Using ICT to document children's learning. Early Childhood Folio, 6, 10-16.

Lewin, C., Scrimshaw, P., Harrison, C., Somekh, B., \& McFarlane, A. (2000). Promoting Achievement: Pupils, teachers and contexts: British Educational Communications and Technology Agency. Available at: http://www.becta.org.uk/research/reports/docs limpact2_prelim2.pdf [20.01.02]

Linderoth, J., Lantz-Andersson, A., \& Lindstrom, B. (2002). Electronic exaggerations and virtual worries: Mapping research of computer games relevant to the understanding of children's game play. Contemporary Issues in Early Childhood: Technology Special Issue, 3 (2), 226-250. Also available at http://www.ioe.ac.uk/cdl/CHAT/pdfs/elecexagger.

Littlejohn, A. H. (2002). Improving continuing professional development in the use of ICT. Journal of computer assisted learning, 18, 166174.

Luke, C. (1999). What next? Toddler netizens, playstation thumb, techno-literacies. Contemporary Issues in Early Childhood, 1 (1), 95100. Retrieved 30 June 2004, from http://www.triangle.co.uk/ciec/

Medvin, M., Reed, D., Behr, D., \& Spargo, E. (2003). Using technology to encourage social problem solving in preschoolers. In G. Marshall \& Y. Katz (Eds.), Learning in school, home, and community. ICT for early and elementary education (pp. 13-20). Boston: Kluwer Academic Publishers.

Ministry of Education. (2000). Guidelines for schools for the online publication of student images and schoolwork. Wellington: Learning Media. Retrieved 14 September 2004, from

http://www.tki.org.nz/r/governance/curriculum/copyguide_e.php

Ministry of Education. (2002). Pathways to the future: Ngā huarahi arataki. A 10-year strategic plan for early childhood education. Wellington: Learning Media.

Mitchell, L., \& Cubey, P. (2003). Characteristics of professional development linked to enhanced pedagogy and children's learning in early childhood settings: Best evidence synthesis. Wellington: Ministry of Education.

Mutch, C. (2003). One context, two outcomes: A comparison of Te Whäriki and the New Zealand Curriculum Framework. In J. Nuttall (Ed.), Weaving Te Whāriki: Aotearoa New Zealand's early childhood curriculum document in theory and practice (pp. 111-126). Wellington: New Zealand Council for Educational Research.

NAEYC. (1996). Technology and young children: ages 3 through 8: A position statement of the National Association for the Education of Young Children. Retrieved 15 July 2004, from

http://www.Itscotland.org.uk/earlyyears/files/ict_framework.pdf

O'Hara, M. (2004). ICT in the early years. London: Continuum.

O'Rourke, M., \& Harrison, C. (2004). The introduction of new technologies: New possibilities for early childhood pedagogy. Australian Journal of Early Childhood, 29 (2), 11-18. Retrieved 25 August 2004, from http://www.ansn.org.au/uploads IORourke_Harrison.pdf

Owen, J., \& Lambert, F. (1996). The Notebook curriculum: an innovative approach to the use of personal computers in the classroom. Australian Educational Computing, 11 (1).

Pastor, E., \& Kerns, E. (1997). A digital snapshot of an early childhood classroom. Educational Leadership, 55 (3), $42-46$.

Patterson, M. (2004). How can ICT enrich the learning environment in early childhood centres? Computers in NZ Schools, 16 (1), 25-30.

Peck, C., Cuban, L., \& Kirkpatrick, H. (2002). Techno-promoter dreams, student realities. Phi Delta Kappan, February 2002, $472-480$.

Pollman, M. J. (2000). Using technology to document children's work. Journal of Early Childhood Teacher Education, 21 (2), $261-267$.

Pramling, I. (1996). Upgrading the quality of early childhood education: Sweden. In P. Klein (Ed.), Early intervention: Cross-cultural experiences with a mediational approach. New York and London: Garland Publishing, Inc.

Reynolds, D. (2002). Misuse of computers unplugged. Times Educational Supplement, January 11,

Romeo, G., Edwards, S., McNamara, S., Walker, I., \& Ziguras, C. (2003). Touching the screen: Issues related to the use of touchscreen technology in early childhood education. British Journal of Educational Technology, 34 (3), 329-339.

Schacter, J. (1999). The impact of education technology on student achievement: What the most current research has to say. Santa Monica, CA: Milken Family Foundation. Retrieved 3 March 2004, from http://www.mff.org/publications/publications.taf?page=161

Sheridan, S., \& Pramling Samuelsson, I. (2003). Learning through ICT in Swedish early childhood education from a pedagogical perspective of quality. Childhood Education, 79 (5), 276-277.

Siraj-Blatchford, I., \& Siraj-Blatchford, J. (2003). More than computers: Information and communication technology in the early years. London: The British Association for Early Childhood Education.

Siraj-Blatchford, J., \& Siraj-Blatchford, I. (2002). Developmentally appropriate technology in early childhood: 'video conferencing'. Contemporary Issues in Early Childhood: Technology Special Issue, 3 (2), 216-225. 
Siraj-Blatchford, J., \& Whitebread, D. (2003). Supporting information and communications technology in the early years. Berkshire: Open University Press.

Stephen, C., \& Plowman, L. (2002). ICT in pre-school settings: A 'benign addition'?: A review of the literature on ICT in pre-school settings. Dundee: Learning and Teaching Scotland. Retrieved 30 June 2004, from http://www.Itscotland.org.uk/earlyyears /BenignAddition.asp

Stephen, C., \& Plowman, L. (2003). ICT in pre-school settings: Benign addition or playroom revolution? Early Childhood Folio, 7, $33-38$.

Steyaert, J. (1997). Peeling the CIS onion: The Looking after Children system in an international perspective. In N. Gould \& K. Moultrie (Eds.), Effective policy, planning and implementation: Information management in social services (pp. 27-47). Aldershot: Avebury.

The Royal Society of Canada. (1999). A review of the potential health risks of radiofrequency field from wireless telecommunications devices. Ontario: An Expert Panel Report prepared at the request of the Royal Society of Canada for Health Canada.

Tubin, D., Mioduser, D., Nachmias, R., \& Forkosh-Baruch, A. (2003). Domains and levels of pedagogical innovation in schools using ICT: Ten innovative schools in Israel. Education and Information Technologies, 8 (2), 127-145.

Van Scoter, J., \& Boss, S. (2002). Learners, language, and technology: Making connections that support literacy: Northwest Regional Educational Laboratory. Retrieved 30 June, 2004, from

http://www.netc.org/earlyconnections/pub/index.html

Van Scoter, J., Ellis, D., \& Railsback, J. (2001). Technology in early childhood education: Finding the balance: Northwest Regional Educational Laboratory. Retrieved 26 July 2004, from

http://www.nwrel.org/request/june01/textonly.html

Verenikina, I., Harris, P., \& Lysaght, P. (2003). Child's play: Computer games, theories of play and children's development. Paper presented at the Young Children and Learning Technologies conference, UWS Parramatta, July 2003.

Whalley, M., \& the Pen Green Centre Team. (2001). Involving parents in their children's learning. London: Sage Publications.

Wilson, P., Clarke, M., Maley-Shaw, C., \& Kelly, M. (2003). "Smile, you're on digital camera!" Collaboration between communities, children, and computers. Early Education, 33 (39-46).

Wright, C. (2001). Children and technology: Issues, challenges, and opportunities. Childhood Education, Fall 2001, 37-41.

Yelland, N. (2002). Playing with ideas and games in early mathematics. Contemporary Issues in Early Childhood: Technology Special Issue, 3 (2), 197-215.

Yelland, N., Grieshaber, S., \& Stokes, J. (2000). Technology in teacher education: Examples of integration and implementation in early childhood courses. Journal of Information Technology for Teacher Education, 9 (1), 95-108. Retrieved 30 June 2004, from http://www.triangle.co.uk/ciec/ 


\title{
Quality and Productivity of Teachers in Selected Public Secondary Schools in Kenya
}

\author{
Maina Moses Ndugu \\ School of Education, Mount Kenya University \\ Email: mainamosesn@gmail.com
}

\section{Doi:10.5901/mjss.2014.v5n5p}

\section{Abstract}

According to the Ministry of Education, science and Technology (MOEST) report of the third Teacher Education Conference in Njoro (1995) the teacher's productivity/performance heavily depends on a number of factors including professional training, attitude, academic background and the education infrastructure of the Institution as well as staff development programmes that are in place at a given time. According to data obtained from Murang'a District Education Office (District Education Office) teaching of sciences is likely to be wanting as reflected in the poor performance of students in KCSE results of 2006. Teacher productivity was measured in terms of student academic performance. It's upon such a background that this study was conducted to explore teacher factors that could be responsible for the poor academic performance of students in Kamacharia Division, Mathioya District, Kenya.

Keywords: Education, Quality, Performance, Teachers, Productivity

\section{Introduction}

Kenya Educational system has expanded significantly since independence. Secondary education has played a significant role in supplying man power needed for economic growth and development in Kenya by creating a class of educated leaders. Planners expect secondary schools and institutions of higher learning to produce the critically needed middle and higher level man power for enhancement of socio - economic development (herbison and Myers 1964)

This explains why Kenya spends substantial amount of Money in Education. The Government continues to increase resources allocated to Education thus in 2004 / 2005 financial year gross expenditure for Ministry of Education estimated to be kshs. 86,123.14 Million representing an increase of $12.2 \%$ from Kshs. 76,724.78 Million. Higher education accounted for $12 \%$ of the total Expenditure recurrent expenditure for higher education increased by $30.3 \%$ (republic of Kenya 2005)

However, developments can not be achieved without addressing the issue of quality teaching. According to Sifuna (1973) there was an attempt to tackle the problem of the quality of Kenyan teachers as early as 1938 when the Christian Missionaries made a proposal for re organization of primary teachers' training. He further noted that a committee headed by hock hart reported on a design to expand the teacher training. The general feeling was that unless the expansion of the teacher education kept pace with the overall rapid growth in the educational system, there was bound to be a problem with educational standards. Abidha (1983) and Ochanda (1983) also shows the fact that the quality of the teacher determine the success of any educational system and the level of educational performance and achievements in examinations. This view is also upheld by the national Committee on Educational Objectives and policies (Republic of Kenya, 1976, 109), which states "the Qualitative attributes of the teachers are of paramount importance in determining the quality of education in which intellectual developments of the child is based."

In this very event, students' are expected to exhibit high academic integrity in form of good grades from schools and job performance after school. In Kenya, there is a big number of students who complete the primary education level and there are more secondary schools than secondary and tertiary institutions. This means that there are many students who are competing for the few posts in secondary and tertiary institutions which calls for better results if one is to successful compete. In addition to this less than half of secondary schools candidates obtain poor grades to take them to secondary schools and one wonders why (Arudo, 2008).

Despite the many measures put in place to improve students' performance, poor grades at National Exams are still prevalent (Enamiroro, 2010). The blame is put to all the stake holders in education like teachers, parents, school management and government. This indicates that the problem of poor performance of students affects everybody in society, for even the employers now and again cry for poor performance of employees, attribute it to poor training in institutions of learning. Without pinpointing who is who, the problem needs immediate solutions, if the country is to be 
transformed from a third world to a medium level of development.

The Education office noted that while performance in other subjects was above average, that of mathematics and sciences was much below the average. The quality of the teaching force, alongside the completion rates and transition rates, are some of the key determinants of efficiency and effectiveness at any level of Education (MOEST 2000) According to UNESCO (1964), whatever the pattern of teaching may be, the teachers part in it is the most important single factor. Given these views, the researcher intends to examine whether there exists a relationship between teacher quality factors such as experience, qualification, motivations, altitude and contact hours with his productivity in terms of students performance in exams at KCSE level in Kamacharia Division Mathioya district of Kenya. It's upon such a back ground that this study was undertaken given the competence of the researcher in teaching having witnessed the problem of poor performance in his school of study.

\section{Research Design}

The researcher used descriptive correlation survey design to investigate the relation between quality and productivity of teachers in Kamacharia division. A combination of qualitative and quantitative method was used. Descriptive survey research studies are designed to obtain pertinent and precise information concerning the current status of phenomenon and whenever possible to draw valid general conclusion from the facts discovered ( Lokesh ,1984 ). The study took the quantitative approach or paradigm in that it was based on variables measured with numbers and analyzed with statistical procedures (Creswell, 2003). The study was co relational in that it was interested in relating quality to productivity of teachers (Charles, 1995), the study was a survey in that it involved a large number of respondents (Best\&Khan, 1993), and cross sectional in so far as pertinent data was collected from all respondents once and for all to reduce on time and costs involved (Creswell, 2003).

\section{Theoretical Framework on Motivation}

\subsection{Maslow's Hierarchy of Needs Theory}

Maslow believed that people who come out of an environment which does not meet their basic needs, tend to experience psychological complaints later in life. Based on the application of this theory to organisational settings, it can be argued that people who do not meet their needs at work will not function efficiently. Maslow's theory is based on two assumptions; that is: people always want more and people arranged their needs in order of importance (Smith \& Cronje, 1992). Maslow (1970) and Schultz, Bagraim, Potgieter, Viedge and Werner (2003) summarised these needs as:

a. Physiological needs. This is the basic need known as the biological needs such as the need for water, food, rest, exercise and sex. Once these needs are met they no longer influence behaviour. An example of this would be trade unions ensuring that their member's basic needs are met because they negotiate for better wages for their members (Smith \& Cronje, 1992).

b. Safety needs. Once the first need is satisfied then the security needs assume precedence. These include the need for job security, insurance and medical aid and the need to feel protected against physical and emotional harm (Smith \& Cronje, 1992).

c. Social needs. This third level of needs is activated once the second level of needs has been adequately met. People have a need for love, friendship, acceptance and understanding from other people. Employees have a tendency to join groups that fulfil their social needs. Managers can play an important part by encouraging people to interact with one another and make sure that the social needs of subordinates are met (Smith \& Cronje, 1992).

d. Ego and esteem needs. The fourth level of needs is the need for self-respect, recognition by others, confidence and achievement. Supervisors can play an active role in satisfying the needs of their employees by recognizing and rewarding high achievers for good performance (Smith \& Cronje, 1992).

e. Self-actualisation needs. This is the highest level of Maslow's hierarchy of needs, and leads to the full development of a person's potential. It is a need where individuals reach full potential and what they want to be become, to utilize all talents well, and to be creative (Glueck, 1974).

Practicing managers have given Maslow's need theory wide recognition, which they ascribe to the theory's intuitive logic and ease of understanding. However, Robbins et al. (2003), argue that research does not validate the theory, since Maslow does not provide any empirical substantiation, and a number of studies that were seeking validation for the theories have similarly not found support for it. 